\title{
Hubungan antara Sikap IImiah dan Hasil Belajar IPA Siswa Kelas V SDN se- Kecamatan Alian Tahun Ajaran 2019/2020
}

\author{
1,2,3Universitas Sebelas Maret \\ alfinurhayati58@gmail.com
}

Alfi Nur Hayati ${ }^{1}$, Joharman ${ }^{2}$, Suhartono ${ }^{3}$

\section{Article History}

accepted 01/06/2020

approved 01/07/2020

published 01/08/2020

\begin{abstract}
This study aims to prove the correlation between scientific attitudes and science learning outcomes to fifth-grade students of public elementary schools in Alian sub-district in the academic year 2019/2020 and the magnitude of the effective contribution of scientific attitude towards science learning outcomes. This research is a quantitative study using the correlation method. Sampling was randomly taken by cluster sampling technique. Correlation test results of scientific attitudes and science learning outcomes indicate that the value of Sig. of 0,000 and the correlation coefficient of 0.316. The contribution of scientific attitude towards the learning outcomes of Natural Sciences is $9.98 \%$. Based on the analysis, it can be concluded that there is a positive correlation between scientific attitudes and learning outcomes of science to fifth-grade students of public elementary schools in Alian sub-district in academic year of 2019/2020.
\end{abstract}

Keywords: scientific attitude, learning outcomes, science

\begin{abstract}
Abstrak
Penelitian ini bertujuan untuk membuktikan adanya korelasi antara sikap ilmiah dan hasil belajar IPA siswa kelas V SDN se-Kecamatan Alian tahun ajaran 2019/2020 dan besarnya sumbangan efektif sikap ilmiah terhadap hasil belajar IPA siswa kelas V SDN se-Kecamatan Alian tahun ajaran 2019/2020. Penelitian ini merupakan penelitian kuantitatif dengan metode korelasi. Pengambilan sampel dihitung menggunakan rumus Slovin dan diambil secara acak dengan teknik cluster sampling. Hasil uji korelasi sikap ilmiah dan hasil belajar IPA menunjukkan bahwa nilai Sig. sebesar 0,000 dan nilai koefisien korelasi sebesar 0,316. Besar sumbangan sikap ilmiah terhadap hasil belajar IPA yaitu 9,98\%. Berdasarkan analisis dan pembahasan hasil penelitian dapat disimpulkan bahwa terdapat korelasi positif antara sikap ilmiah dan hasil belajar IPA siswa kelas V SDN se-Kecamatan Alian tahun ajaran 2019/2020.
\end{abstract}

Kata kunci: sikap ilmiah, hasil belajar, IPA 


\section{PENDAHULUAN}

Belajar merupakan bagian yang penting dalam proses pendidikan seseorang. Belajar adalah perubahan tingkah laku yang relatif tetap yang didapatkan dari pengalaman. Menurut Slameto (2013: 2), belajar adalah proses yang dilakukan seseorang untuk memperoleh perubahan tingkah laku yang baru secara keseluruhan, sebagai hasil dari pengalaman dalam berinteraksi dengan lingkungan. Melalui belajar, siswa diharapkan dapat mengalami peningkatan sikap, pengetahuan, dan keterampilan. Hal tersebut sesuai dengan pendapat Suyono \& Hariyanto (2014: 9) yang menyatakan bahwa belajar adalah suatu proses untuk memperoleh pengetahuan, meningkatkan keterampilan, memperbaiki perilaku, sikap dan menguatkan kepribadian. Untuk mengetahui sejauh mana proses belajar siswa dapat dilihat dari hasil belajar siswa tersebut.

Hasil belajar adalah kemampuan yang dimiliki oleh siswa setelah mengikuti pembelajaran. Menurut Sudjana (2016: 3) hasil belajar adalah perubahan tingkah laku yang mencakup bidang kognitif, afektif, dan psikomotoris. Hasil belajar yang diperoleh setiap siswa dipengaruhi oleh bagaimana proses belajar siswa tersebut. Menurut Aunurrahman (2016: 178-185), proses dan keberhasilan belajar siswa dipengaruhi oleh faktor internal dan faktor eksternal. Faktor internal adalah segala faktor dari dalam diri siswa yang mempengaruhi proses dan hasil belajar siswa. Faktor internal terdiri dari karakteristik siswa, motivasi belajar, sikap terhadap belajar, rasa percaya diri, serta kebiasaan belajar. Sedangkan faktor eksternal merupakan faktor dari luar diri siswa yang terdiri dari sekolah dan lingkungan sosial. Berdasarkan beberapa faktor yang diuraikan di atas, salah satu faktor penting yang mempengaruhi hasil belajar siswa adalah sikap.

Sikap merupakan sesuatu yang dipelajari dan menentukan bagaimana seseorang bereaksi terhadap keadaan serta menentukan apa yang dicari oleh seseorang dalam hidup (Slameto, 2013: 191). Sikap yang dimiliki oleh seorang siswa seharusnya adalah sikap yang mampu mendorong keberhasilan belajar siswa salah satunya adalah sikap ilmiah. Menurut Jenkins (Astuti, 2014: 11) sikap ilmiah adalah kecenderungan untuk berpikir dan bertindak dalam langkah - langkah yang bersifat ilmiah. Sikap ilmiah menunjukkan bagaimana sikap dalam belajar, mengatasi masalah, melaksanakan tugas, dan meningkatkan kemampuan diri. Oleh karena itu, sikap ilmiah sangat diperlukan dalam proses pembelajaran siswa, salah satunya dalam ilmu pengetahuan alam (IPA). Hal tersebut sesuai dengan pendapat Trianto (2014: 137) yang menyatakan bahwa IPA menuntut sikap ilmiah seperti terbuka, jujur, dan rasa ingin tahu.

Berdasarkan hasil wawancara dengan guru, kondisi sikap ilmiah siswa masih perlu ditingkatkan lagi. Hal tersebut dapat dilihat dari rendahnya rasa ingin tahu siswa, maraknya budaya menyontek, siswa mengeluh ketika mengerjakan soal dengan tingkat kesulitan yang tinggi, serta siswa tidak serius dalam mengerjakan tugas dari guru. Selain itu, proses pembelajaran IPA yang memberikan pengalaman langsung dan kegiatan praktik belum dapat dilaksanakan dengan maksimal karena keterbatasan waktu dan sarana prasarana. Hal tersebut menyebabkan verbalisme pada siswa karena sebagian besar materi tidak diikuti dengan kegiatan praktik. Selain itu, pembelajaran yang didominasi metode ceramah dapat menyebabkan siswa menjadi pasif, kurang berminat dalam belajar dan berakibat pada hasil belajar yang kurang 
maksimal. Hal ini dapat dilihat dari rata- rata hasil PTS siswa yang masih berada di bawah KKM.

Sikap ilmiah merupakan salah satu faktor penting yang mendorong tercapainya hasil belajar yang maksimal. Hasil penelitian yang dilakukan oleh Putri, Idrus, \& Yennita (2017: 8) menunjukkan adanya korelasi yang positif antara sikap ilmiah dengan hasil belajar kognitif siswa. Penelitian lain yang dilakukan oleh Sihombing (2016: 96) menunjukkan adanya hubungan yang signifikan antara sikap ilmiah dengan hasil belajar biologi siswa dengan kontribusi sebesar $57,4 \%$ terhadap hasil belajar biologi siswa.

Berdasarkan uraian di atas, penulis tertarik untuk meneliti korelasi antara sikap ilmiah dengan hasil belajar IPA siswa kelas V SDN se-Kecamatan Alian. Adapun tujuan dari penelitian ini adalah untuk membuktikan korelasi antara sikap ilmiah dengan hasil belajar IPA dan besar sumbangan sikap ilmiah terhadap hasil belajar IPA siswa kelas V SDN se-Kecamatan Alian Tahun Ajaran 2019/2020.

\section{METODE}

Penelitian ini merupakan penelitian kuantitatif dengan metode korelasi. Variabel pada penelitian ini terdiri dari variabel bebas $(X)$ yaitu sikap ilmiah dan variabel terikat $(Y)$ yaitu hasil belajar IPA. Populasi dari penelitian ini adalah seluruh siswa kelas V SDN se-Kecamatan Alian Kabupaten Kebumen Tahun Ajaran 2019/2020 sebanyak 849 siswa dengan sampel sebanyak 202 siswa. Teknik sampling yang digunakan yaitu teknik probability sampling jenis cluster sampling.

Teknik yang digunakan dalam mengumpulkan data adalah angket dan tes. Angket digunakan untuk mengumpulkan data penelitian sikap ilmiah. Angket sikap ilmiah berupa angket dengan jenis skala likert yang berbentuk checklist. Pembuatan instrumen sikap ilmiah dikembangkan dari 10 aspek dan 26 indikator. Aspek - aspek tersebut yaitu rasa ingin tahu, jujur, tekun, kritis, disiplin, kerja sama, tanggung jawab, mawas diri, sikap penemuan, dan berpikiran terbuka. Tes digunakan untuk mengumpulkan data hasil belajar IPA. Tes yang digunakan dalam penelitian ini berupa soal pilihan ganda materi IPA kelas $\mathrm{V}$ semester 1 sebanyak 33 soal pada ranah kognitif C1 hingga C4.

Uji validitas pada penelitian ini menggunakan analisis korelasi Product Moment Pearson dan pada uji reliabilitas menggunakan Cronbach Alpha. Berdasarkan hasil uji validitas, angket sikap ilmiah yang terdiri dari 104 butir angket terdapat 90 butir angket yang valid, instrumen tes IPA yang terdiri dari 50 soal terdapat 33 soal yang valid. Uji reliabilitas angket sikap ilmiah menunjukkan nilai 0,957 dan tes hasil belajar IPA 0,838 sehingga kedua instrumen tersebut dapat dikategorikan reliabel sangat tinggi.

Uji prasyarat data penelitian ini yaitu uji normalitas data, uji linieritas data, serta metode suksesif interval. Setelah semua uji prasyarat terpenuhi, data tersebut kemudian dianalisis menggunakan teknik korelasi Pearson Product Moment dengan bantuan aplikasi SPSS. Hipotesis untuk analisis korelasi penelitian ini yaitu:

$\begin{array}{cccc}\mathrm{H}_{0} \quad: \rho=0 & 0 \text { berarti tidak ada hubungan antara sikap ilmiah dengan } \\ \mathrm{Ha} & : \rho \neq 0 & \text { hasil belajar IPA }\end{array}$

Kriteria pengujian (berdasar signifikansi) yaitu:

Jika signifikasi $\geq \alpha$ maka terima $\mathrm{H}_{0}$

Jika signifikasi $<$ a maka tolak $\mathrm{H}_{0} \rightarrow$ a yang digunakan yaitu $5 \%$ atau 0,05 . 
Selain menganalis korelasi, penelitian ini juga menganalisis sumbangan efektif. Analisis sumbangan efektif menggunakan rumus sebagai berikut:

$\mathrm{SE}=(\mathrm{SR}) \times\left(\mathrm{R}^{2}\right)$

Keterangan :

$$
\begin{array}{ll}
\mathrm{SE} & =\text { sumbangan efektif } \\
\mathrm{R}^{2} & =\text { koefisien determinasi } \\
\mathrm{SR} & =\text { sumbangan relatif }
\end{array}
$$

\section{HASIL DAN PEMBAHASAN}

Penelitian ini dilakukan dengan memberikan angket sikap ilmiah dan soal tes IPA kepada siswa kelas V di SD yang menjadi sampel penelitian. Berdasarkan hasil analisis data, dapat dideskripsikan hasil belajar IPA dan sikap ilmiah serta korelasi antara sikap ilmiah dan hasil belajar IPA. Rata-rata skor hasil belajar IPA adalah 18,59 dari skor maksimal 33. Rata-rata skor sikap ilmiah adalah 307,17 dari skor maksimal 450. Rata-rata pada masing-masing aspek sikap ilmiah dapat dilihat pada gambar 1.

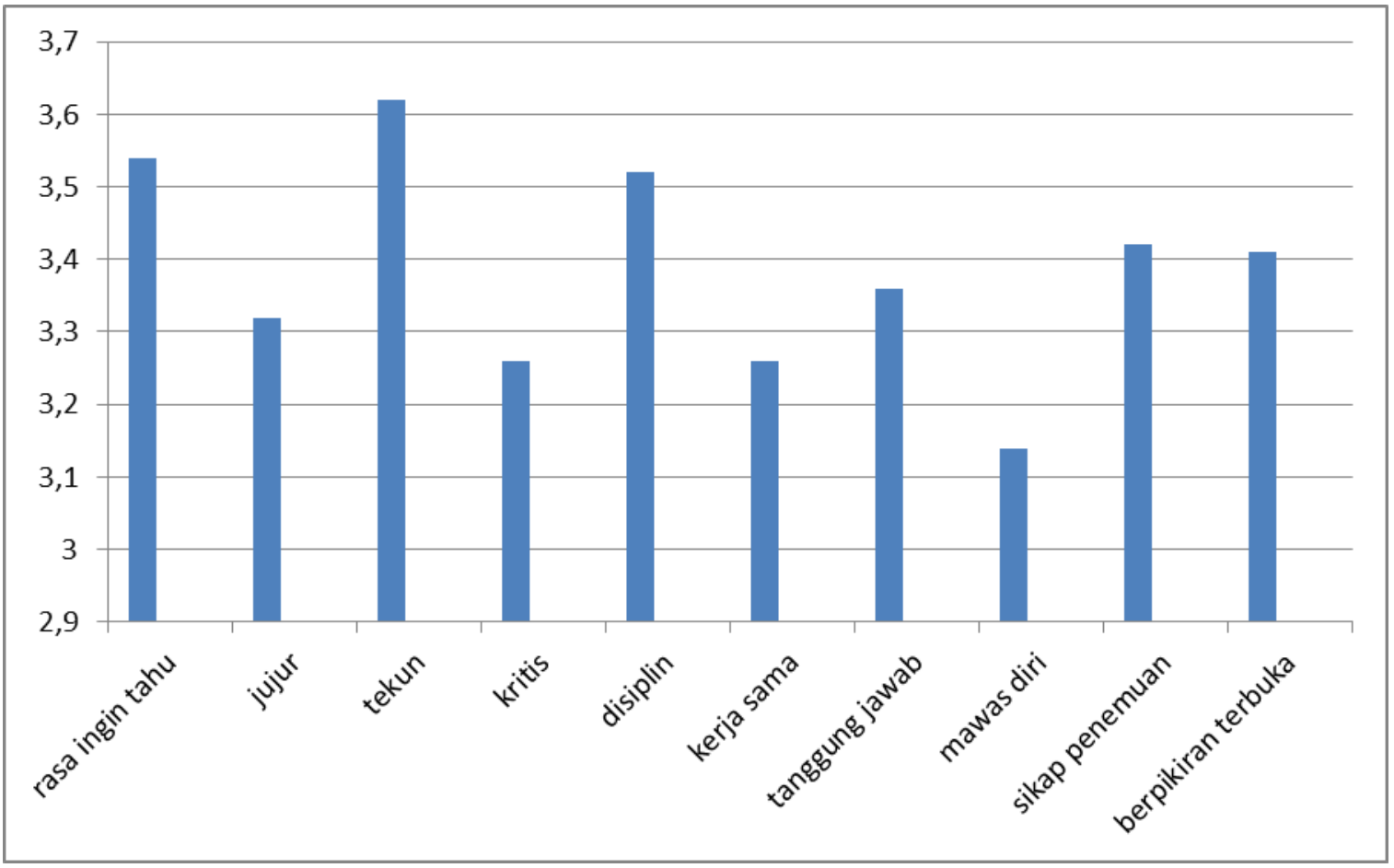

Gambar 1. Rata - rata Skor Aspek Sikap IImiah

Uji prasyarat data pada penelitian ini telah terpenuhi yaitu data berdistribusi normal, data linier, serta telah ditransformasi menjadi data interval. Uji normalitas dilakukan dengan menggunakan metode Kolmogorov-Smirnov yang menunjukkan nilai signifikansi sebesar 0,52 pada variabel $X$ dan nilai signifikansi sebesar 0,200 pada variabel $\mathrm{Y}$. Kedua variabel menunjukkan nilai $>0,05$ sehingga dapat disimpulkan kedua variabel tersebut berdistribusi normal. Uji linieritas menunjukkan nilai Sig. 
Deviation from Linearity sebesar 0,172 . Nilai signifikansi tersebut $>0,05$ sehingga dapat disimpulkan bahwa terdapat hubungan linier antara variabel $\mathrm{X}$ dan variabel $\mathrm{Y}$. Setelah uji prasyarat analisis data terpenuhi, selanjutnya dilakukan uji hipotesis berupa uji korelasi dan sumbangan efektif.

Uji korelasi digunakan untuk mengetahui hubungan antara sikap ilmiah dan hasil belajar IPA. Analisis korelasi yang digunakan yaitu analisis korelasi Pearson Product Moment menggunakan aplikasi SPSS. Hasil uji korelasi antara sikap ilmiah dan hasil belajar IPA ditampilkan pada tabel berikut ini.

Tabel 1. Hasil Uji Korelasi antara Sikap IImiah dan Hasil Belajar IPA

\begin{tabular}{llrr}
\hline \multicolumn{3}{c}{ Correlations } & \\
\hline \multirow{2}{*}{ sikapilmiah } & Pearson Correlation & 1 &, $316^{* *}$ \\
& Sig. (2-tailed) & &, 000 \\
& $\mathrm{~N}$ & 202 & 202 \\
hasilbelajar & Pearson Correlation &, $316^{* *}$ & 1 \\
& Sig. (2-tailed) &, 000 & \\
& $\mathrm{~N}$ & 202 & 202 \\
\hline
\end{tabular}

Hasil uji korelasi antara sikap ilmiah dan hasil belajar IPA menunjukkan nilai koefisien korelasi sebesar 0,316 dan nilai Sig. yaitu 0,000. Nilai Sig. $(0,000)<\alpha(0,05)$, menunjukkan hipotesis awal ditolak, terdapat korelasi antara sikap ilmiah dengan hasil belajar IPA siswa kelas V SDN se-Kecamatan Alian Tahun Ajaran 2019/2020. Hasil penelitian ini sesuai dengan penelitian yang dilakukan oleh Astuti (2014) tentang "Analisis Korelasi antara Sikap IImiah dan Prestasi Belajar Siswa Kelas VIII SMPN 4 Bengkulu pada Pembelajaran IPA Biologi dengan Model Siklus Belajar 5E" yang menunjukkan koefisien korelasi sebesar 0,358 lebih besar dari $r$ tabel 0,339 sehingga dapat disimpulkan terdapat korelasi positif antara sikap ilmiah dan prestasi belajar siswa. Penelitian lain yang relevan yaitu penelitian yang dilakukan oleh Putri, Idrus, Yennita (2017) tentang "Analisis Korelasi Sikap IImiah dan Hasil Belajar Kognitif Siswa melalui Model PBL" yang menunjukkan nilai signifikansi 0,005 lebih kecil dari 0,05 sehingga dapat disimpulkan sikap ilmiah berkolerasi dengan hasil belajar kognitif siswa.

Berdasarkan uraian di atas dapat diketahui bahwa sikap ilmiah memiliki korelasi dengan hasil belajar IPA siswa. Selain itu, nilai koefisien korelasi pada penelitian ini juga bernilai positif artinya kenaikan pada skor sikap ilmiah akan diikuti kenaikan skor hasil belajar dan penurunan skor sikap ilmiah akan diikuti penurunan skor hasil belajar siswa. Hal tersebut sesuai dengan pendapat Wahyudi (2013: 27) bahwa siswa yang memiliki sikap ilmiah tinggi cenderung lebih mudah dalam belajar, mudah menerima dan mengolah informasi serta terampil dalam memecahkan suatu masalah sedangkan siswa yang memiliki sikap ilmiah rendah kurang dapat menguasai pelajaran karena kesadaran yang kurang dalam menghadapi suatu permasalahan sehingga hasil belajarnya pun kurang baik. Menurut Syah (Astuti, 2014: 56) siswa dengan sikap ilmiah yang positif pada umumnya akan memperoleh dampak yang positif pula terhadap prestasi belajarnya sebagai representasi usaha-usaha yang telah dilakukannya selama proses pembelajaran. Sebaliknya jika sikap ilmiah siswa 
cenderung negatif maka pada umumnya prestasi belajarnya tidak sebaik siswa yang sikap ilmiahnya positif.

Selain membuktikan korelasi antara sikap ilmiah dan hasil belajar IPA siswa kelas $\mathrm{V}$, penelitian ini juga bertujuan untuk mengetahui besar sumbangan sikap ilmiah terhadap hasil belajar IPA siswa kelas V. Berdasarkan hasil perhitungan sumbangan efektif didapatkan persentase sebesar sebesar 9,98\%, artinya persentase sumbangan variabel sikap ilmiah terhadap hasil belajar IPA sebesar 9,98\% dan sisanya sebesar $90,02 \%$ dipengaruhi oleh faktor lain. Hal tersebut dapat terjadi karena banyak faktor lain yang mempengaruhi hasil belajar siswa seperti minat belajar, kemandirian belajar, motivasi, guru, serta lingkungan sosial siswa. Menurut Saefullah (2012: 172-176) faktor yang mempengaruhi belajar digolongkan menjadi dua yaitu faktor internal yang terdiri dari intelegensi, motivasi, sikap, pancaindra, dan kesehatan badan serta faktor eksternal yang terdiri dari pendidikan orang tua, perhatian orang tua, sosial ekonomi keluarga, kompetensi guru, metode mengajar, kurikulum, sarana prasarana, dan sosial budaya.

\section{SIMPULAN}

Berdasarkan hasil penelitian mengenai korelasi sikap ilmiah dan hasil belajar IPA siswa kelas V se-Kecamatan Alian tahun ajaran 2019/2020 dapat ditarik kesimpulan bahwa sikap ilmiah berkorelasi positif dengan hasil belajar IPA. Korelasi positif artinya kenaikan pada skor sikap ilmiah akan diikuti kenaikan skor hasil belajar dan penurunan skor sikap ilmiah akan diikuti penurunan skor hasil belajar siswa. Sumbangan sikap ilmiah terhadap hasil belajar IPA sebesar 9,98\% dan sisanya sebesar $90,02 \%$ dipengaruhi oleh faktor lain seperti minat belajar, kemandirian belajar, motivasi, guru, serta lingkungan sosial siswa.

\section{DAFTAR PUSTAKA}

Astuti, E. J. (2014). Analisis Korelasi antara Sikap IImiah dan Prestasi Belajar Siswa Kelas VIII5 SMPN 4 Bengkulu pada Pembelajaran IPA Biologi dengan Model Siklus Belajar 5E. Skripsi Tidak Dipublikasikan, Universitas Bengkulu, Bengkulu.

Aunurrahman. (2016). Belajar dan pembelajaran. Bandung : Alfabeta.

Putri, A.T., Idrus, I., \& Yennita. (2017). Analisis Korelasi Sikap Ilmiah dan Hasil Belajar Kognitif Siswa melalui Model PBL. Jurnal Diklabio, 1 (1), 1-9. Diperoleh 8 November 2019, dari https://ejournal.unib.ac.id > index.php > jppb > article > view.

Saefullah. (2012). Psikologi Perkembangan dan Pendidikan. Bandung: Pustaka Setia

Sihombing, C. (2016). Hubungan Keterampilan Metakognitif dan Sikap IImiah dengan Hasil Belajar Biologi Siswa Kelas XI SMAN se-Kabupaten Tapanuli Utara. Jurnal Dunia IImu, 2(1), 96-107. Diperoleh 12 November 2019, dari http://www.jurnalmudiraindure.com/wp-content/uploads/2016/03/.

Slameto. (2013). Belajar: dan Faktor - Faktor yang Mempengaruhinya. Jakarta: Rineka Cipta.

Sudjana, N. (2016). Penilaian Hasil Proses Belajar Mengajar. Bandung: PT Remaja Rosdakarya. 
Suyono \& Hariyanto. (2014). Belajar dan Pembelajaran. Bandung: PT Remaja Rosdakarya.

Trianto. (2014). Model Pembelajaran Terpadu: Konsep, Strategi, dan Implementasinya dalam Kurikulum Tingkat Satuan Pendidikan. Jakarta : Bumi Aksara.

Wahyudi. (2013). Analisis Kontribusi Sikap IImiah, Motivasi Belajar dan Kemandirian Belajar terhadap Prestasi Belajar Mahasiswa Prodi Pendidikan Fisika STKIP PGRI Pontianak. Jurnal Edukasi Matematika dan Sains, 1(2), 20-31. Diperoleh 27 November 2019, dari http://ejournal.unipma.ac.id/ index.php/JEMS/ article/ view/123. 